\title{
Perbandingan Pengukuran Tekanan Darah Pada Lengan Normal Dan Lumpuh Pada Penderita Stroke
}

\author{
Zuliani Zuliani*, Mukhammad Rajin*, Nurul Khoirun Nisa*, Fitri Firranda Nurmalisyah** \\ *Fakultas Ilmu Kesehatan Universitas Pesantren Tinggi Darul 'Ulum Jombang \\ **STIKES Pemkab Jombang \\ Email: zuliani@ fik.unipdu.ac.id
}

\begin{abstract}
Abstrak
Tekanan darah terdiri dari tekanan sistol dan diastole. Stroke adalah gangguan otak yang disebabkan oleh proses patologis dalam sistem pembuluh darah otak. Stroke dapat menyebabkan berbagai defisit neurologis. Tujuan dari penelitian ini untuk Perbandingan Pengukuran Tekanan Darah di Lengan Kiri dan Lengan Lumpuh pada Pasien Stroke.

Jenis penelitian ini adalah kuantitatif dengan desain penelitian deskriptif. Populasi penelitian adalah pasien stroke yang memiliki parese di Rumah Sakit Mojowarno yang terdiri dari 45 responden yang dipilih menggunakan simple random sampling dan instrumen menggunakan kuesioner. Hasil penelitian yang diperoleh Responden Gender sebagian besar laki-laki 30 orang (66\%) dan berusia 61-70 tahun sebanyak 25 orang (56\%) dan hampir setengah dari responden tingkat sekolah dasar sebanyak 22 orang (49\%) dan sebagian besar pekerjaannya adalah pribadi sebanyak 27 orang (61\%). Sedangkan pengukuran tekanan darah responden dengan rerata hand systole dengan nilai 145 dan rerata diastole dengan nilai 92, sedangkan rerata ekstremitas sistol dengan nilai 147 dan rerata diastole dengan nilai 94. Tidak ada perbedaan dalam hal ini. hasil pengukuran tekanan darah. antara sisi tangan normal dengan sisi parese tangan. Baik sisi normal dan sisi tangan yang parese memiliki peluang atau kemungkinan yang sama untuk menghasilkan hasil yang lebih tinggi atau lebih rendah. Hasil ini juga digunakan untuk membuktikan bahwa pengukuran tekanan darah di satu sisi tangan tidak dapat mewakili pengukuran di kedua tangan karena kelainan pembuluh darah dapat terjadi di mana saja baik di tangan kanan dan kiri, sehingga pemeriksaan hanya pada satu sisi tangan dapat menyebabkan buruk interpretasi hasil yang benar. Kata kunci: Pengukuran tekanan darah, stoke
\end{abstract}

\section{Abstract}

Blood pressure consists of pressure systole and diastole. Stroke is a brain disorder caused by a pathological process in the blood vessel system of the brain. Stroke can cause various neurological deficits. The aim of this study to Comparison of Blood Pressure Measurements in the Left Arm and Paralyzed Arm in Stroke Patients.

This type of research is quantitative with descriptive research design. The study population was stroke patients who had parese in Mojowarno Hospital consisting of 45 respondents selected using simple random sampling and instruments using questionnaires. The results of the study obtained Respondents Gender mostly male 30 people (66\%) and aged 61-70 years as many as 25 people $(56 \%)$ and almost half of the respondents were elementary school level as many as 22 people (49\%) and most of the work was private as much 27 people (61\%). Whereas the measurement of respondent's blood pressure with mean hand systole with a value of 145 and mean diastole with a value of 92, while the mean extremity of systole with a value of 147 and mean diastole with a value of 94 . There is no difference in blood pressure measurement results. between the sides of the normal hand with the parese side of the hand. Both the normal and hand side of the hand that parese has the same opportunity or possibility to produce higher or lower results. This result is also used to prove that the measurement of blood pressure on one side of the hand cannot represent measurements on both hands because vascular abnormalities can occur anywhere both right and left hand, so that examination of just one side of the hand can cause poor interpretation of results right.

Keywords: Measuring Blood Pressure, Stroke 


\section{PENDAHULUAN}

Stroke merupakan gangguan neurologik mendadak yang berdampak pada suplai darah ke otak berhenti (Price \& Wilson, 2012). Trombosis, embolisme, iskemia dan hemoragi bisa menyebabakan stroke (Smeltzer, 2002). Menurul Lam (2007), mengatakan efek stroke tergantung dari area yang terkena dan dapat menyebabkan kelemahan dan kelumpuhan, kesulitan berbicara dan menelan, dan menurunnya kesadaran.

Menurut Yoshida (2012), Indonesia adalah stroke terbesar di Asia, yang menjadi urutan penyakit kardiovaskular, kanker, kemudian stroke. Jadi stroke merupakan penyebab kematian ketiga didunia (Corsalini, 2009). Meningkat sebesar 8,3\%, Jawa Timur penderita sroke peringkat ke empat se Indonesia 12,1 per 1.000 penduduk,.(RISKESDAS, 2013).

Tekanan darah yang normal pasti diinginkan setiap orang, dengan itu mampu menjalankan aktifitasnya dengan tanpa gangguan. Berbagai masalah yang timbul pada tekanan darah, diantaranya tekanan darah tinggi (hipertensi) dan tekanan darah rendah (hipotensi), dikarenakan faktor aktifitas yang tidak seimbang, lingkungan, pola hidup yang tidak sehat. Dalam keadaan istirahat (duduk atau berbaring) adalah posisi paling baik untuk mengukur tekanan darah (Guyton and Hall, 2007).
Stroke adalah kelainan otak akibat dari kelainan sistem pembuluh darah. Pengukuran tekanan darah sangat penting untuk di ukur oleh perawat dengan menggunakan stetoskop dan sphygmomanometer, dengan cara hati hati dan sesuai dengan prosedur operasional untuk menghindari kesalahan karena akan berdampak pada hasil dari pengukuran darah (Wallymahmed, 2008).

Ada beberapa penelitian yang tidak sejalan, oleh Sunarno (2007) yang menyatakan adanya perbedaan pengukuran tekanan darah lengan tangan yang normal dengan parese pasien stroke. Berbeda dengan penelitian oleh Fadli (2011), menunjukkan tidak ada beda pengukuran tekanan darah antara lengan tangan normal dengan parese. Di lapangan saat melakukan pengukuran takanan darah perawat seringkali tidak memperhatikan bagian lengan yang mana yang mengalami parese, perawat hanya mengukur salah satu bagian dari lengan tangan pasien, baik yang mengalami parese atau yang tidak, yang diduga hasilnya tidak akurat.

Adanya perbedaan tekanan darah tersebut disebabkan oleh masalah yang berkaitan dengan hipertensi, antara lain faktor usia, pembuluh darah perifer, oklusi pembuluh darah, pulsus paradoksus, dan gangguan pada jantung. Dengan hal tersebut, sebaiknya pengukuran tekanan darah pada empat ekstremitas. 
Pemeriksaan pada satu ekstremitas biasanya dibenarkan apabila teraba denyut nadi yang normal dan apabila ada keraguan denyut nadi, ke empat ekstremitas harus dilakukan pengukuran tekanan darah (Price \& Lorraine, 2006).

Berdasarkan uraian diatas penulis tertarik untuk meneliti "mengetahui gambaran pengukuran tekanan darah pada lengan normal dan lumpuh pada penderita stroke" sehingga dapat memberi informasi mengenai perbedaan takanan darah lengan normal dengan lumpuh penderita stroke, sehingga lebih berhati-hati dalam melakukan pengukuran tekanan darah, terutama pada penderita stroke.

\section{METODE PENELITIAN}

Desain dalam penelitian ini kuantitatif dengan desain penelitian deskriptif. Populasi dalam penelitian ini adalah penderita stroke yang mengalami lumpuh di ICU RSK Mojowarno Jombang. Kriteria inklusi: Pasien stroke yang mengalami hemiparese atau hemiplegi dan Pasien atau keluarga bersedia menjadi responden Pasien yang berusia antara 4565 tahun. Kriteria eksklusi adalah pasien yang meninggal pada saat dilakukan evaluasi. Sampel dalam hal ini adalah 45 responden menggunakan sampling acak sederhana dan instrumen lembar observasi.

\section{HASIL PENELITIAN}

\section{Karakteristik responden}

Tabel 1: Deskripsi pasien stroke pada bulan Agustus - September 2014

\begin{tabular}{|c|l|l|}
\hline $\begin{array}{c}\text { Karakteristik } \\
\text { Responden }\end{array}$ & Frekuensi & Presntasi \\
\hline Jenis kelamin & & \\
\hline- Laki-laki & 30 & 66 \\
\hline- Perempuan & 15 & 44 \\
\hline Total & 45 & 100 \\
\hline Umur & 6 & \\
\hline $41-50$ & 14 & 13 \\
\hline $51-60$ & 25 & 31 \\
\hline $61-70$ & 45 & 56 \\
\hline Total & & 100 \\
\hline Pendidikan & 10 & \\
\hline Tidak sekolah & 22 & 23 \\
\hline SD & 7 & 49 \\
\hline SMP & 3 & 17 \\
\hline SMA & 2 & 7 \\
\hline PT & 45 & 4 \\
\hline Total & & 100 \\
\hline Pekerjaan & 12 & \\
\hline Tidak bekrja & 27 & 26 \\
\hline Swasta & 6 & 61 \\
\hline PNS & 45 & 13 \\
\hline Total & 100 \\
\hline
\end{tabular}

Responden Jenis kelamin sebagian besar laki-laki 30 orang (66\%) dan berusia 61-70 tahun sebanyak 25 orang (56\%) dan hampir setengah responden tingak pendidikannya SD sebanyak 22 orang (49\%) dan sebagian besar pekerjaannya swasta sebanyak 27 orang ( $61 \%$ ).

Tabel 2: Deskripsi tekanan darah pasien stroke pada bulan AgustusSeptember 2014

\begin{tabular}{|l|c|c|}
\hline \multirow{2}{*}{ Keterangan } & \multicolumn{2}{|c|}{ Tekanan darah } \\
\cline { 2 - 3 } & Mean sistole & Mean diastole \\
\hline Lengan lumpuh & 145 & 92 \\
\hline Lengan normal & 147 & 91 \\
\hline
\end{tabular}

Responden dengan nilai rata-rata lengan lumpuhs mean sistole dengan nilai 145 dan mean diastole dengan nilai 92, sedangkan lengan normal mean sistole dengan nilai 147 dan mean diastole dengan nilai 94. 


\section{Pembahasan}

Berdasarkan jenis kelamin responden sebagian besar laki-laki 30 orang (66\%) dan sebagian kecil perempuan 15 orang (44\%), lebih banyak laki-laki dari perempuan. Berdasarkan penelitian oleh Chih-Ying Wu et.al (2008), mengatakan bahwa kejadian penderita stroke laki-laki $(63,4 \%)$ lebih tinggi dari pada perempuan $(36,6 \%)$, sejalan dengan penelitian Hardi Yanis (2004) di RSUP Dr.Kariadi dengan 66 sampel, didapatkan penderita stroke perempuan $(59,1 \%)$ dari pada laki-laki 40,9\%. Hal ini tidak sejalan dengan penelitian yang dilakukan oleh Wolfe et.al, penderita stroke sebanyak 1.254 orang, perempuan $(51,6 \%)$ lebih banyak dari pada laki-laki $(48,4 \%)$.

Menurut penelitian Ghani et.al (2016), menyatakan beda, perempuan lebih banyak dari laki-laki dengan beda selisih sebesar 1,2\%, sejalan dengan Sacco, et.al (1997) bahwa penderita stroke laki-laki 1,25 kali lebih banyak dari pada perempuan. Menurut American Heart Association/AHA (2006), menyatakan serangan stroke lebih banyak laki-laki 81,7 per 100.000 dari pada perempuan 71,8 per 100.000 dikarenakan konsumsi alkohol, merokok, dislipidemia dan berhubungan dengan lifestyle.

Berdasarkan umur 61-70 tahun sebanyak 25 responden (56\%) dan sebagian kecil umur 41-50 tahun sebanyak 6 responden (13\%). Hal ini sejalan dengan penelitian Yesanti (2014), dapat dilihat bahwa penderita berusia di atas 50 tahun $(81,25 \%)$ dan di bawah 50 tahun(18,75\%), sejalan dengan penelitian Mochammad Bahrudin (2009), didapatkan kejadian stroke usia > 50 tahun $(69,7 \%)$, dan yang lainnya terjadi usia <50 tahun, dengan terbanyak usia 51-60 tahun.

Faktor risiko yang tidak dapat diubah adalah salah satunya umur semakin meningkat maka risiko terjadi stroke juga meningkat, disebabkan sistem pembuluh darah mengalami penurunan. Menurut Wahjoepramono (2005), menyatakan faktor umur menjadi faktor risiko 2 kali lipad setelah usia $\geq 55$ tahun. Sedangkan Framingham menunjukkan bahwa risiko penderita stroke akan meningkat pada umur 45 - 55 (20\%), 55 - 64 (32\%), dan $65-74(83 \%)$.

Hasil penelitian dari Maulidiyah (2015), menyatakan umur tidak hubungannya dengan kejadian jenis stroke, dan faktor usia tidak menjadi faktor utama terjadinya stroke hemorhagic maupun stroke non hemorhagic. Sejalan dengan penelitian, yang menyatakan umur tidak berhubungan dengan kejadian stroke (Sitorus, Hadisaputra, dan Kustiowati, 2010)

Serangan stroke sekarang menyerang umur yang lebih muda. Hal ini 
sesuai sejalan dengan Riyadina dan Rahajeng (2013), bahwa seseoranga berisiko mengalami stroke lebih banyak berumur 35-44 tahun. Sejalan dengan Ghani, Mihardja dan Delima (2016), menunjukkan responden terbanyak usia 35-44 tahun, kemudian 15-24 tahun, dimana sekarang muncul pada kelompok usia muda sebesar $0,3 \%$. Penelitian yang lain menunjukkan bahwa responden lebih banyak berumur 38-40 tahun dan berjenis kelamin laki-laki 73,7 \%. American Heart Association dan Goldstein, dkk (2006), mengungkapkan bahwa serangan stroke lebih banyak laki-laki dari pada perempuan (Burhanuddin, Wahiduddin, dan Jumriani, 2013).

Berdasarkan pendidikan, bahwa responden hampir setengahnya berpendidikan SD sebanyak 22 orang (49\%) dan sebagian kecil sebanyak 2 orang (4\%), sejalan dengan Maulidiyah (2015) bahwa karakteristik penderita stroke berpendidikan sebagian responden pada kelompok kasus paling banyak berpendidikan PT yaitu sebesar 34,8\%, sedangkan kelompok kontrol responden berpendidikan SD yaitu sebesar 30,4\%.

Berdasarkan pekerjaan responden sebagian besar bekerja swasta sebanyak 27 orang $(61 \%)$ dan sebagian kecil sebanyak 6 orang (13\%), sejalan dengan Maulidiyah (2015), Karakteristik pekerjaan diketahui bahwa sebagian responden pada kelompok kasus memiliki pekerjaan sebagai PNS/TNI/POLRI sebesar 32,6\%. Sedangkan pada kelompok kontrol respondenSebagian memiliki pekerjaan sebagai Petani yaitu sebesar $34,8 \%$.

Hasil penelitian yang dilakukan pada responden menunjukkan bahwa lengan yang normal dengan tangan yang lumpuh pada pasien stroke selisih nilai rata-rata tangan lumpuh dan normal adalah 2. Hal ini menunjukkan bahwa ada sedikit perbedaan di antara keduanya, tekanan darah yang meningkat mempengaruhi aliran darah ke otak yang berdampak terjadinya aterosklerosis yang lebih parah serta lesi spesifik pada arteri intraserebral. Adanya lesi ini merupakan gejala yang sulit dipahami dan namun stenosis $>70 \%$ secara garis lurus berhubungan dengan risiko terjadinya infark serebral (Mohr,J.P.,et al., 2007). Penelitian lain yang menyatakan semakin tinggi tekanan darah risiko terjadi stroke juga meningkat, peningkatan tekanan darah (sistolik) akan meningkat dengan adanya bertambahnya usia (Goldstein, et. Al, 2006).

Disisi lain sebagian besar responden merupakan pasien stroke serangan pertama, sehingga pada hasil pengukuran tekanan darah belum tampak adanya perbedaan tekanan darahlengan normal dan lumpuh. Aliran darah tergantung dari tekanan pendorong darah dan resistensi aliran yang saling 
berlawanan. Aliran darah bertambah apabila tekanan pendorong darah meningkat, dan sebaliknya aliran akan berkurang apabila resistensi meningkat adanya perbedaan tekanan antara dua tempat agar darah dapat mengalir di antara kedua tempat tersebut.

Sebagai respon perbedaan tekanan, darah bisa mengalir di sirkulasi sistemik arteria ke vena, yang mengubah tekanan atrium kanan adalah tekanan arteri dan vena. Semua ini tergantung dari aliran balik vena ke atrium dan kemampuan mengosongkan diri. Curah atrium kanan dan peningkatan tekanan atrium kanan dapat dikurangi dengan cara adanya gangguan katup trikuspidalis dan ventrikel kanan. Resistensi disebut juga sebagai penentu aliran darah, terutama oleh radius pembuluh darah. Besar resistensi aliran bisa di ubah oleh kekentalan darah dan panjang pembuluh, tetapi relative konstan pengaruhnya tidak berarti (Sylvia \& Lorraine, 2006).

Tekanan darah bisa di ukur pada beberapa arteri, tekanan darah normal sering ditemukan dikedua lengan (tidak boleh $>5-10 \mathrm{mmHg}$ ), perbedaan $>10$ $\mathrm{mmHg}$ indikasi terjadinya gangguan vaskuler, apabila (>20-30 $\mathrm{mmHg}$ ) adanya suspek terhadap gangguan di aliran darah pada daerah yang tekanan darahnya rendah (Potter \& Perry, 2005).
Hasil penelitian ini menyatakan hipertensi sedang dan berat mempunyai peluang sangat besar terjadinya gangguan vaskuler yang mempengaruhi perbedaan hasil pengukuran tekanan darah, oleh karena itu sebaiknya melakukan pengukuran pada kedua tangan terutama pada penderita hipertensi baru. Ganong (2008), mengungkapkan bahwa pengukuran tekanan darah harus dilakukan pada kedua tangan.

Hasil Penelitian oleh Yesanti (2014), mengatakan bahwa ada beda ratarata tekanan sistole dan diastole dari 25 responden menunjukkan tidak ada perbedaan rata-rata hasil pengukuran tekanan darah pada sisi tangan yang normal maupun sisi tangan yang parese. Hal ini menunjukkan bahwa baik kedua sisi tangan mempunyai kemungkinan yang sama untuk hasil yang lebih tinggi atau lebih rendah. Pembuktian bahwa pengukuran tekanan darah satu sisi tangan tidak bisa mewakili pengukuran kedua tangan karena kelainan pembuluh darah bisa terjadi dimana saja sehingga interpretasi hasil yang kurang tepat.

Adanya perbedaan tekanan sistolik pada penderita terjadi pada 25\%, sedangkan tekanan diastolik $15 \%$ penderita. Hasil serupa penelitian lain bahwa ada $30,3 \%$ memiliki perbedaan tekanan sistolik sebesar $10 \mathrm{mmHg}$ atau lebih, sedangkan diastolik sebesar 10 
mmHg atau lebih sebanyak 21,2\% penderita (Constan (1991) dalam Nursalam dan Siti Pariani (2001))

Serangan stroke bisa terjadi mendadak, kapanpun, siapapun, dan dimanapun. Stroke bisa menyebabkan defisit neurologis tergantung pembuluh darah dan jumlah aliran darah sekunder atau sensori (kolateral). Kontraksi otot dipengaruhi oleh parese tangan maupun kaki, suplai darah ke otak belakang dan otak tengah juga menyebabkan berkurangnya kontraksi otot. Hal itu dapat menghambat hantaran jaras-jaras utama antara otak dan medulla spinalis, dan secara total menyebabkan ketidakmampuan sensoris motoris yang abnormal. Berkurangnya suplai darah pada pasien stroke salah satunya diakibatkan oleh ateriosklerosis. Dinding pembuluh darah akan kehilangan elastisitas dan sulit berdistensi, sehingga diganti oleh jaringan fibrosa yang tidak dapat meregang dengan baik yang dapat mempengaruhi tekanan darah (Potter \& Perry, 2005).

\section{KESIMPULAN DAN SARAN}

\section{Kesimpulan}

Berdasarkan pasien stroke yang mengalami kelumpuhan, didapatkan sedikit perbedaan nilai rata-rata tekanan darah sisi tangan parese dan normal baik sistole maupun diastole, disisi lain sebagian besar responden adalah usianya lebih dari 60 tahun, serangan pertama, sehingga pada hasil pengukuran tekanan darah belum tampak adanya perbedaan tekanan darah antara lengan yang normal dengan lumpuh. Baik sisi lengan yang normal maupun lumpuh mempunyai kemungkinan yang sama untuk lebih tinggi atau lebih rendah. Terbukti bahwa pengukuran tekanan darah pada salah satu sisi lengan tidak bisa mewakili pengukuran pada kedua lengan karena kelainan pembuluh darah dapat terjadi mendadak, kapanpun, siapapun, dan dimanapun baik lengan kanan maupun kiri, sehingga pemeriksaan salah satu lengan saja bisa menyebabkan hasil yang kurang tepat.

\section{Saran}

Pentingnya dalam pengukuran tekanan darah pada kedua tangan, khususnya pada pasien dengan penyakit hipertensi baru karena kedua tangan baik sisi yang normal maupun sisi yang parese mempunyai kemungkinan untuk hasil yang lebih tinggi atau lebih rendah.

\section{DAFTAR PUSTAKA}

Association (AHA/ASA). (2006). Primary prevention of ischemic stroke. http://stroke.ahajournals.org/cgi/co ntent/ full/37/6/1583\# FIG1173987 diperoleh tanggal 4 September 2016. 
Burhanuddin, M., Wahiduddin, dan Jumriani. (2013). Faktor Risiko Kejadian Stroke pada Dewasa Awal (18-40 Tahun) di Kota Makasar Tahun 2010-2012.

Corsalini M, Rapone B, Grassi FR, Di Venere D . (2009) . A study on oral rehabilitation in stroke patients: Analysis of a group of 33 pa- tients. Gerodontology;27:178-182.

Ganong (2008). Buku Ajar Fisiologi Kedokteran, Edisi 22. EGC : Jakarta.

Ghani, L., Mihardja, L. K., dan Delima (2016). Faktor Risiko Dominan Stroke di Indonesia. Buletin Penelitian Kesehatan. Vol 44 No. 1, Maret 2016: 49-58.

Goldstein, L.B., Adams, R., Alberts, M. J., Appel, L. J., Brass, L. M., Bushnell, C. D., Culebras, A. (2006).

Guyton, Arthur C. dan Hall,John E. (2007). Buku Ajar Fisiologi Kedokteran.EGC: Jakarta.

Lam OLT, McMillan AS, Samaranayake LP, Li LSW, McGrath C. (2013). Effect of oral hygiene interventions on opportunistic pathogens in patients after stroke. Am J Infect Control;41: 149-154.

Maulidiyah, dkk. (2015). Faktor-faktor Yang Berhubungan Dengan Kejadian Stroke Iskemik Pada Pasien Rawat Inap Di RSUD Soedarso Pontianak.

Nursalam (2011). Konsep \& Penerapan Metodologi Penelitian Ilmu Keperawatan, Pedoman Skripsi, Tesis \& Instrumen Penelitian Keperawatan. Salemba : Jakarta.

Potter, P. A. \& Perry, A.G. (2005). Buku Ajar Fundamental Keperawatan : Konsep, Proses, Dan Praktik, Edisi 4 , Volume 2. Alih Bahasa ;
Renata Komalasari , dkk. EGC : Jakarta.

Price, S.A \& Wilson, L.M. (2012). Patofisiologi konsep klinis proses proses penyakit. Jakarta: Volume 2. EGC

Riyadina, W. dan Rahajeng, E. (2013). Determinan Penyakit Stroke. Journal FKM UI.

Sacco, et al,. (1997). Risk factors for ischemic stroke. http://www.americanheart.org/ presenter.jhtml?identifier $=4716$ diperoleh tanggal 14 September 2016.

Sitorus, R.J., Hadisaputro, S., dan Kustiowati, E. (2010). Faktorfaktor Risiko yang Mempengaruhi Kejadian Stroke pada Usia Muda Kurang dari 40 Tahun di Rumah Sakit di Kota Semarang. (http://esprint.undip.ac.id/6482/1/

Rico_Januar_Sitorus.pdf) diakses pada 27 April 2015.

Sunarno.(2007). Analisis Perbedaan Hasil Pengukuran Tekanan Darah antara Lengan Kanan dengan Lengan Kiri pada Penderita Hipertensi di RSUD DR. H. Abdul Moeloek Propinsi Lampung. http://repository.usu.ac.id/bitstream /123456789/24749/2/Reference.pdf . Diakses tanggal 30 Januari. Jam 17.10 WIB.

Smeltzer, Suzanne C. 2002. Buku Ajar Keperawatan Medikal Bedah. Jakarta: EGC

Wahjoepramono, E. J. (2005). Stroke tatalaksana fase akut. Jakarta: Universitas Pelita Harapan.

Wallymahmed M. (2008) Blood pressure measurement Nursing Standard 22(19): $\quad$ 45-8. http://www.cetl.org.uk/learning/pri 
nt/blood-pressure print.pdf.

Diakses tanggal 30 januari. Jam 17.00 WIB.

Yoshida M, Murakami T, Yoshimura O, Akagawa Y.(2012). The evaluation of oral health in stroke patients. Gerodontology. 2012;29:e489-4 